\title{
RISALAH|
}

DOI: $10.24014 /$ jdr.v31i1.8882

\section{PARADOKS KOMUNIKASI-DAKWAH FUNDAMENTALIS SALAFI: KASUS MASJID NURUL JAM'IYAH JAMBI}

\author{
Adeni \\ Universitas Islam Negeri Walisongo Semarang \\ Email: adeni@walisongo.ac.id
}

\section{Kata kunci \\ Fundamentalis Salafi, Masjid Nurul \\ Jam'iyyah,}

Komunikasi Dakwah

\section{Abstrak}

Artikel ini bertujuan menganalisis paradoks komunikasi-dakwah kelompok fundementalis salafi. Pertanyaan yang diajukan adalah apa bentuk dakwah kelompok fundamentalis salafi sehingga sering dicap sebagai intoleran dan term fundamentalisme Islam dituduh sebagai sesuatu yang negatif? Penelitian ini menggunakan penelitian kualitatif berdasarkan wawancara, observasi, dan dokumentasi pada Masjid Nurul Jam'iyyah Jambi. Artikel ini menunjukkan bahwa kelompok salafi berdakwah secara strik dan rigid. Pendekatan yang mereka gunakan adalah pendekatan komunikasi dakwah top-down yang cenderung memaksa penerima dakwah ketimbang mengedepankan komunikasi Islam yang menekankan egalitariasnime dan komunikasi dua arah yang memberikan kebebasan kepada si penerima untuk menerima atau menolak pesan dakwah. Karenanya, paradoks dakwah salafi tidak terletak pada karakter fundamentalisme atau substansi dakwah yang mereka perjuangkan, tetapi pada cara komunikasi-dakwah yang mereka gunakan. Istilah fundamentalisme sama sekali tidak bermasalah dalam konteks keberagamaan (keberislaman) seseorang. Sebaliknya, komunikasi-dakwah yang tidak tepat dapat membuat term fundamentalisme menjadi negatif.

\footnotetext{
Abstract

This article aims to analyze the dawa-communication paradoxes of the salafi-fundamentalits by questioning of what is the da'wah form of salafi-fundamentalist, so it is often labeled as intolerant and the term of fundamentalism is accused of being negative? The study focuses on the case of Masjid Nurul Jami'yyah, Jambi. By using qualitative research conducted with interview, observation and documentation, this paper concludes that da'wah of the salafi group is strickly and rigidly done. They are using the top-down communication approach as a seculer model of communication that tend to force da'wah recipients, and ignoiring the Islamic communication model emphasizing egalitarianism and two ways communication giving the recipient the freedom to accept or reject the da'wah message. The paradox of the salafi dawah lies not in the character or substansce of fundamentalism that they stand for, but in the way of da'wa-communication they use. The term of fundamentalism has absolutely no problem in a person's religious context. Conversely, improper preaching can make the term fundamentalism being negative.
} 


\section{Pendahuluan}

Artikel ini mengkaji tentang komunikasi-dakwah kelompok fundamentalis salafi di Masjid Nurul Jam'iyyah Desa Talang Pantai Muara Bungo Jambi. Apa yang terjadi di Masjid ini adalah pergulatan dan kontestasi antara kelompok fundamentalis salafi dan masyarakat setempat yang dipimpin oleh K.H. Abdullah Amsir. Kelompok salafi melalui pengajiannya berusaha mengikis tradisi keislaman yang telah lama mengakar dalam kehidupan masyarakat. Kedatangan kelompok baru yang menamakan diri mereka sebagai pengikut salaf dan pengamal sunnah di masjid tersebut mendapat perlawanan dari jama'ah setempat.

Kelompok salafi menyuarakan Islam murni yang merujuk kepada asas fundamental Islam, yaitu al-Qur'an dan al-Sunnah, berdasarkan pada tradisi Nabi dan para salaf salih. Kelompok ini menolak amaliyah keagamaan (keislaman) yang tidak ada tuntunannya secara tekstual di dalam dua sumber tersebut. Pemahaman rigid keagamaan semacam ini berujung pada tindakan pengangambil-alihan Masjid Nurul Jam'iyyah, yang umum digunakan oleh jama'ah setempat. Akibatnya, masyarakat setempat dan kelompok salafi terlibat dalam persitegangan (resistensi).

Studi tentang dinamika dakwah salafi ini dapat ditemukan dalam beberapa penelitian terdahulu. Su'adi Asy'ari (2013) dalam "Managing Islamic Public Space Responses of Sumantran Malay Muslims toward Neo-anti Bid'ah Movement" melakukan studi terhadap kelompok neo anti bid'ah di masyarakat Melayu Jambi. Asy'ari memotret beberapa masjid sebagai ruang publik keagamaan di Kota Jambi yang berubah menjadi ruang perseteruan antara kelompok neo anti-bid'ah dengan masyarakat setempat karena persoalan furu'iyyah. Hal ini sejalan dengan penelitian Din Wahid (2012) dalam "Challenging Religious Authority the Emergence of Salafi Ustadhs in Indonesia". Wahid menyimpulkan bahwa telah terjadi dinamika tarik menarik otoritas keagamaan antara Ustadz salafi dan Kiyai setempat dalam melakukan dakwah dan menguasai ruang publik keagamaan seperti masjid dan pengajian. Secara lebih terang, Wahib (2017) dalam "Being Pious among Indonesian Salafis," menegaskan dakwah salafi di Indonesia tidak hanya mengarah pada upaya puritanisasi tapi juga Arabisasi. Wahib menemukan begitu populernya penggunaan nama panggilan yang berasal dari bahasa Arab, seperti $a b i$, umi, ami dan ama di antara mereka sendiri sebagai upaya mengganti nama Jawa atau nama bernuansa ke-Indonesia-an. Kesalehan mereka sebenarnya ditujukan untuk merespon tradisionalitas dan modernitas, akan tetapi di saat yang sama mereka justru membuat jarak dengan kelompok yang lain.

Yakin (2018) dalam "Salafi Dakwah and the Dissemination of Islamic Puritanism in Indonesia: A Case Study of the Radio of Rodja," menyimpulkan bahwa dakwah salafi di radio tidak siap menerima demokrasi dan perbedaan pendapat dari kelompok lain yang berbeda. Demikian pula Lisnyansky (2018) dalam "From da'wa in Europe to European Da'wa: The Muslim Brotherhood and the Salafiyya in France and Britain," juga memberikan kesimpulan yang sama di mana salafi tidak mau berinteraksi 
dengan kelompok lain melainkan dalam hal-hal yang sejalan dengan manhaj yang mereka yakini.

Selain itu, terdapat pula beberapa penelitian dengan kesimpulan yang berbeda, seperti penelitian Chaplin (2018) berjudul "Salafi Activism and the Promotion of a Modern Muslim Identity: Evolving Mediums of Da'wa Amongst Yogyakarta University Students." Ia menyimpulkan bahwa dakwah salafi di Jogjakarta berjalan cukup massif. Mereka berusaha membangun identitas muslim modern dengan meluruskan nilai-nilai keislaman yang berkembang di masyarakat. Hitchens (2018) dalam "Salafism in America History, Evolution, Radicalization" yang melakukan riset di Amerika menyimpulkan bahwa dakwah salafi di Amerika mencoba berbaur dan beradaptasi dengan sosial masyarakat, bahkan mereka mencoba melawan ekstremisme melalui ideology salafi.

Kesimpulan demikian juga dapat ditemukan dari penelitian Bangstad \& Ling (2015) dalam 'Da'wa is Our Identity'-Salafism and IslamNet's Rationales for Action in a Norwegian Context" yang melihat bahwa dakwah salafi dapat menyesuaikan diri dengan situasi sosial-politik yang berkembang. Mereka menggarisbawahi bahwa perubahan dari model salafi puritan menuju salafi yang berorientasi politik adalah hal yang dapat dilakukan dalam batas tertentu untuk kepentingan dakwah. Hal ini pula tampaknya ditekankan Boubekeur (2008) dalam penelitiannya berjudul "Salafism and Radical Politics in Postconflict Algeria." Ia mencoba mempertimbangkan bahwa dakwah salafi dapat menjadi jalan hidup bagi masyarakat di Algeria.

Dinamika dakwah salafi juga menemukan ruangnya secara bebas dalam konteks kemajuan media. Kesimpulan seperti ini dapat ditemukan di antara dalam penelitian Adeni (2016) dalam tesis tentang "Rodja TV sebagai Media Islam Salafi". Tesis ini menyimpulkan bahwa salafi sengaja berdakwah menggunakan media untuk menghindari terjadi resistensi dengan tradisi keislaman masyarakat, dan melalui media, salafi mampu mengambil perhatian masyarakat. Senada dengan itu, Sunarwoto (2016) dalam "Salafi Dakwah Radio: A Contest for Religious Authority," melihat bahwa salafi yang terbagi ke dalam banyak varian kelompok menjadikan media modern dalam kegiatan dakwahnya. Penelitian Iqbal (2014) berjudul "Internet, Identity and Islamic Movements: The Case of Salafism in Indonesia," juga menunjukkan hal yang sama bahwa internet sangat berkontribusi besar dalam membantu salafi menyebarkan ideologi mereka ke dalam kehidupan masyarakat, bahkan dalam upaya perlawanan mereka terhadap para kelompok jaringan Islam Liberal (JIL).

Dari beberapa penelitian di atas terlihat masih belum ditemukan studi yang secara spesifik melihat dakwah salafisme dalam konteks komunikasi-dakwah dan fundamentalisme. Studi yang penulis lakukan ini berusaha memotret komunikasi dakwah yang ditampilkan kelompok salafi dalam kegiatan dakwahnya yang fundamentalis dan sangat strik dalam mempertahankan pokok-pokok ajaran Islam, sehingga di satu sisi dakwah mereka bersitegang dengan sosial keagamaan masyarakat 
yang didakwahi. Meluai analisis komunikasi-dakwah yang dipadukan dengan analisis fundamentalisme, penelitian ini diharapkan dapat menemukan faktor-faktor penyebab terjadinya resistensi antara salafi dengan sosial keagamaan masyarakat. Untuk itu, peneliti menggunakan konsep komunikasi dakwah dan konsep fundamentalisme.

Fundamentalisme sering dinilai sementara kalangan sebagai penyebab munculnya ekstremitas dakwah bahkan tindakan terorisme (Appleby 2000; Michael, 2004; Bar, 2008), padahal fundamentalisme tidaklah demikian. Muhammad Imarah (1968: 22) mempertanyakan keabsahan peristilahan fundamentalisme dalam konteks Islam. Islam tidak mengenal fundamentalisme dengan karakter sebagaimana di Barat. Istilah tersebut dipadankan dengan istilah al-ushuliyat yang berarti dasar-dasar agama. Adalah sesuatu yang wajar ketika seseorang yang beragama berpegang teguh dengan dasar-dasar agamanya.

Khaled Abou e-Fadl (2005) juga melihat penggunaan istilah tersebut sebagai sesuatu yang problematik dalam Islam. Menurutnya, penggunaan fundamentalisme dalam Dunia Kristen sangat wajar untuk kaum ekstremis Kristen yang bersikeras menggunakan makna literal dari Bibel. Namun dalam konteks Islam, istilah tersebut dipadankan dengan istilah ushul yang berarti orang-orang yang bersandar pada hal-hal yang bersifat pokok. Istilah fundamentalisme Islam sejatinya, tegas el-Fadl (2005), tidak melulu menjadi milik mereka yang berpegang teguh pada al-Qur'an dan Hadis, tetapi juga dapat disandarkan kepada muslim liberal progressif dan moderat yang tidak jarang merujuk kepada pokok-pokok Islam dalam setiap diskursus yang mereka bangun. Hanya saja perbedaannya adalah kelompok pertama (yang sering disebut fundamentalis Islam) diasosiasikan sebagai kelompok negative, sedangkan kelompok kedua (yang sering disebut liberalis Islam) tidak harus menanggung anggapan negatif.

Selain itu, Andereas Armborst (2004) menjelaskan bahwa tidak ada keterkaitan antara fundamentalisme Islam dengan tindak kekerasan apalagi terorisme. Ambrost mengidenfitikasikan fundamentalisme Islam dengan salafisme, yang mempunyai ciri antara lain: penentangannya terhadap consensus modernisme dan sekulerisme yang dibuat oleh rekan seiman mereka yang modernis. Demikian pula John L. Esposito (2010) yang cenderung menggunakan istilah 'revivalisme Islam dan Islamis' untuk gerakan keagamaan seperti Ikhwan al-Muslimin di Mesir yang berhasil membangun masyarakat menjadi lebih islami. Mereka terlibat dalam kehidupan sosial sebagai psikolog, wartawan, pengacara, ilmuan politik dan sebagainya. Aktivitas mereka tersebar dalam banyak lembaga seperti sekolah-sekolah Islam, klinik kesehatan, rumah sakit, pelayanan sosial, dan lembaga penerbitan.

Dalam konteks komunikasi dakwah, upaya yang dilakukan dapat menjembatani ragam perbedaan di dalam Islam. Ini dibangun di atas kenyataan bahwa dakwah Islam, mengutip Abdul Karim Zaedan (1975), adalah murni mengajak orang kepada jalan Allah, yaitu agama Islam, yang harus dilakukan dengan cara-cara yang baik. Dalam tradisi dakwah dikenal tiga metode utama, yaitu al-Hikmah, al-Mau'idzhah 
Hasanah, dan al-Mujadalah bi al-Ahsan (Q.S. Al-Nahl: 125). Tiga metode ini adalah metode komunikasi dakwah, yang sejalan dengan teknik komunikasi informative, persuasive, human relation, bukan koersif (Penny Powers, 2007). Karenanya, tidak ada paksaan atas orang lain untuk menerima dakwah. Egalitarianisme dakwah Islam dapat ditemukan pula dari konsep komunikasi Islam Hamid Mowlana (2007), dengan konsep tabligh yang anti-pemaksaan.

Branston dan Stafford (2010) juga memiliki pandangan yang sama. Menurutnya seseorang mengidentifikasi dirinya sebagai pembaca atau pendengar atau penerima yang aktif. Mereka tidak lagi menjadi penerima yang pasif yang hanya menjadi korban penipuan dan pencucian otak oleh pengirim pesan.

Para Ulama klasik telah menerapkan dakwah anti paksaan ini. Mereka seringkali berbeda dalam setiap ijtihad yang dilakukan, tetapi perbedaan itu tidak membuat satu dengan yang lain saling memaksakan pendapat. Imam Abu Hanifah dan Imam al-Syafi'i mengatakan, "apabila ditemukan Hadist shahih, maka itulah mazhabku." Imam Malik berkata: "tidak satupun orang yang datang setelah Nabi yang boleh diambil dan ditinggalkan ucapannya kecuali ucapan Nabi SAW." Sementara itu, Imam Ahmad (2006) mengatakan, "siapa yang menolak hadits Rasulullah, maka ia berada ditepi jurang kehancuran". Para Imam mazhab menyadari bahwa masing-masing mereka tidak bisa mengabsolutkan apa yang mereka hasilkan dari ijtihadnya.

Ali Tanthawi sebagaimana dihimpun oleh Mujahid Ma'mun Diraniyah (2008) juga menyebutkan bahwa ketika mendakwahkan persoalan khilafiyah, seorang da'i harus memberikan kemudahan kepada mad'u untuk mengikuti sesuatu yang memudahkan bagi mereka. Tanthawi mencontohkan, jika terjadi khilafiyah tentang shalat Tarawih antara 8 dan 20 rakaat misalnya, maka tidak perlu dipermasalahkan, karena hal itu termasuk ke dalam wilayah khilafiyah di mana setiap orang bebas menentukan pilihannya.

Teknik komunikasi-dakwah yang tepat merupakan aspek penting dalam proses transmisi pesan-pesan keislaman. Suatu pesan keislaman yang bersumber dari alQur'an dan Hadits yang diformat dalam bahasa komunikasi-dakwah dengan teknik yang tepat akan tampil sebagai bahasa yang inklusif. Jadi, teknik komunikasi dakwah dapat melakukan filterisasi terhadap pesan-pesan keislaman sehingga selaras dengan kebutuhan mad'u.

Selain itu, dakwah bukanlah instrument penghancur tatanan sosial yang telah mapan. Pada batas tertentu, dakwah bukan hanya ditujukan untuk memperbanyak pengikut, tetapi hanyalah jalan untuk mengajak orang ke jalan yang lebih baik. Andi Faisal Bakti (2000) mengatakan, "kebaikan yang ditebarkan dari kegiatan dakwah haruslah berupa kedamaian dalam wujud Islam yang toleran dan inklusif. Para da'i dituntut untuk lebih fleksibel, kosmopolit, pluralis, dan egaliter." Hal ini sejalan dengan dakwah yang dicontohkan oleh Rasulullah SAW yang lebih menekankan sifat wasatiyah (moderat) (Rajab, 2011). Wasatiyah ini paling tidak bisa ditumbuhkan dengan cara melakukan penafsiran yang terbuka terhadap ayat-ayat al-Qur'an dan Hadis. Nasarudin Umar (2011) menyatakan, deradikalisasi bukan dimaksudkan sebagai 
upaya untuk menyampaikan pemahaman baru tentang Islam, dan bukan pula pendangkalan akidah, melainkan sebagai upaya mengembalikan dan meluruskan kembali pemahaman tentang apa dan bagaimana Islam.

Untuk usaha itu, bahasa dakwah dapat memerhatikan kecenderungan masyarakat di suatu tempat. Al-Qur'an Surat Ibrahim ayat 4 menegaskan:

"Kami tidak mengutus seorang Rasul pun, melainkan dengan bahasa kaumnya, supaya Ia dapat memberi penjelasan dengan terang kepada mereka. Maka Allah menyesatkan siapa yang Dia kehendaki, dan memberi petunjuk kepada siapa yang Dia kehendaki. Dan Dia-lah Tuhan yang Maha Kuasa lagi Maha Bijaksana.'

Ayat ini memberikan penjelasan bahwa dakwah harus menggunakan pendekatan bahasa atau budaya suatu masyarakat yang didakwahi. Hanya dengan cara itu dakwah akan mudah diterima. Ahmad Musthafa al-Maraghi (1998) ketika mengomentari ayat ini menyebutkan bahwa tujuan Allah mengutus para rasul dengan bahasa kaumnya adalah untuk memudahkan umatnya dalam menerima dan memahami petunjuk Allah.

Gagasan di atas menunjukkan bahwa menjadi fundamentalis bukanlah suatu persoalan dalam beragama, bahkan dalam bermasyarakat. Persoalan terjadi ketika pesan dakwah dipaksakan untuk diterima orang lain. Di sinilah dakwah kelompok fundamentalis salafi dapat dikaji. Dalam kasus yang terjadi di Masjid Nurul Jamiyyah, resistensi masyarakat setempat terhadap dakwah salafi pada dasarnya dapat dilihat sebagai permasalahan komunikasi dakwah, bukan persoalan fundamentalisme. Fundemantalisme lebih merupakan ideologi, sikap, dan komitmen keberagamaan yang sifatnya sangat eksklusif, sementara komunikasi dakwah merupakan cara-cara inklusif dalam menyosialisasikan atau memasyarakatkan suatu keyakinan (ideologi, sikap, dan komitmen keberagamaan).

Artikel ini akan menjawab pertanyaan apa bentuk dakwah kelompok fundamentalis salafi sehingga sering dicap sebagai intoleran dalam kaitannya dengan fundamentalisme Islam yang menjadi ciri khas dakwah salafi.

\section{Metode}

Penelitian ini merupakan studi kualitatif dengan pendekatan komunikasidakwah. Pendekatan komunikasi-dakwah digunakan karena penelitian ini akan menganalisis komunikasi dakwah kelompok salafi dalam kaitannya dengan fundamentalisme Islam. Data yang akan digali adalah data-data lapangan, yaitu data tentang pergulatan salafi dan masyarakat setempat di Masjid Nurul Jamiyyah Jambi.

Untuk pengumpulan data, peneliti melakukan wawancara dengan tokoh agama masyarakat setempat dalam hal ini K.H. Abdullah Amsir, Ahmad, Roziq, Mala, Mukaromah, dan Ina. Selain itu peneliti juga melakukan observasi/pengamatan langsung terhadap kegiatan pengajian di Masjid tersebut. Objek yang diamati adalah kegiatan setelah shalat, perdebatan antara masyarakat dan kelompok salafi, 
keberpisahan salafi dari jama'ah setempat dalam hal berjamaah shalat. Dokumentasi juga diperlukan untuk menggali informasi lebih jauh tentang pengajian-pengajian yang dilakukan di masjid tersebut seperti jadwal pengajian, undangan rapat, catatan rapat masjid, dan sejenisnya, serta kitab-kitab yang digunakan dalam pengajian.

Setelah data terkumpul dilakukan analisis menggunakan pendekatan komunikasi-dakwah dan fundemantalisme Islam. Data-data diinterpretasi dengan prinsip-prinsip yang berlaku dalam komunikasi-dakwah Islam, seperti dakwah Islam yang tidak boleh dilakukan dengan paksaan, harus dengan keterbukaan dan fleksibelitas. Lalu dikaitkan dengan prinsip fundamentalisme Islam yang rupanya tidak identik dengan kekerasan, terorisme atau ekstremisme dakwah.

Akhirnya artikel ini diharapkan dapat membuktikan setidaknya dua hal, yaitu pertama, istilah fundamentalisme dalam Islam bukanlah istilah yang negatif. Kedua, konotasi negatif fundamentalisme Islam bisa bermula dari kekeliruan dalam mengomunikasi-dakwahkan pemahaman keislaman, bukan pada istilah fundamentalisme itu sendiri.

\section{Hasil dan Pembahasan}

Masjid Nurul Jam'iyyah merupakan salah satu masjid kaum Muslimin di Desa Talang Pantai Muara Bungo Jambi. Tidak jauh berbeda dengan Masjid kebanyakan, sejak berdirinya, masjid ini aktif digunakan oleh masyarakat setempat untuk shalat berjama'ah dan mengadakan kegiatan-kegiatan pengajian dan dakwah. Pada hari-hari besar Islam, seperti Maulid Nabi, Isra wa al-Mi'raj, Nuzul Qur'an, dan lain-lain, jamaah masjid ini tidak pernah ketinggalan dalam melaksanakan kegiatan-kegiatan tersebut (Wawancara dengan Ahmad, Mei 2019).

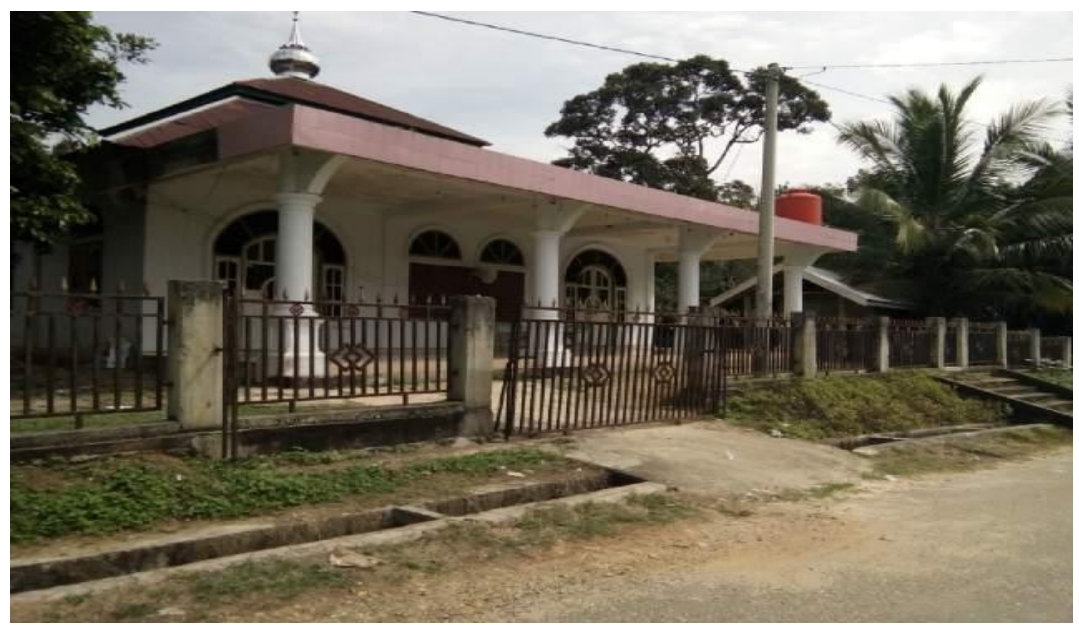

Sumber: Hasil Penelitian

Gambar 1. Masjid Nurul Jam'iyyah Talang Pantai Muara Bungo 
Masjid ini selalu ramai dihadiri oleh masyarakat setempat ketika shalat lima waktu, terlebih pada bulan Ramadhan, hari Raya Idul Fitri dan Idul Adha, masjid ini selalu tidak memadai untuk menampung jama'ah shalat. Selain itu, di masjid ini diadakan kegiatan Yasinan dan Tahlilan secara berjama'ah setelah shalat Magrib pada setiap malam Jum'at kemudian dilanjutkan dengan tausiyah agama yang disampaikan oleh seorang tokoh agama, yang dikenal dengan Tuan Guru Amsir.

Pengajian Guru Amsir ini boleh dikatakan sebuah pengajian yang terorganisir dengan baik. Ia mengajarkan kitab-kitab Arab Melayu, seperti Kifayatul Awam, Kitab Perukunan, dan Kitab Sayr Salikin. Di samping itu, ia juga menggunakan kitab berbahasa Arab seperti Fathul Qarib, Syarh al-Bajuri, al-Adzkar, Riyadh al-Salihin, Subulus Salam, dan Tafsir Ibn Katsir (Wawancara dengan Guru Amsir, Mei 2019). Pengajiannya dimulai dengan membaca al-Fatihah yang dihadiahkan untuk orang-orang yang telah meninggal dunia, khususnya, al-Fatihah Tabarruk, meminta keberkahan agar diberi kemudahan dalam mengkaji kitab-kitab Ulama yang diajarkannya. Setelah pengajian, dibacakan do'a kafaratul majlis (Observasi, Mei 2019).

Di samping kegiatan pengajian Guru Amsir, masjid ini sesekali juga didatangi oleh kelompok Jama'ah Tabligh yang melakukan khuruj selama beberapa hari, dan terkadang sampai satu bulan (Wawancara dengan Roina, Juni 2019). Tidak ada masalah yang terjadi ketika masjid ini dimanfaatkan oleh para Jama'ah Tabligh untuk pengajianpengajian mereka, karena mereka sama sekali tidak membicarakan persoalan khilafiyah. Permasalahan kemudian mulai muncul ketika kelompok fundamentalis salafi hadir dan menggelar pengajian di masjid ini.

Kelompok baru ini mengidentifikasikan dirinya sebagai pengikut salaf salih (Lubis, 2016: 200-201). Kedatangan kelompok ini bermula dari Ustadz Abdul Muiz, seorang pendakwah salafi dari Sumatera Barat, yang menyelenggarakan kajian berbasis sunnah di masjid tersebut. Awalnya kajian ini disukai masyarakat setempat karena branding "kajian berbasis sunnah" yang ia promosikan (Wawancara dengan Ismail, Mei 2019). Namun setelah mendapat ruang di masjid tersebut, mereka mulai melakukan kritik-kritik frontal terhadap pengajian Guru Amsir yang dianggap sebagai penyebar bid'ah. Tidak hanya itu, mereka, dengan berpegang kuat kepada al-Qur'an dan alSunnah secara tekstual-literal, mencoba melakukan koreksi terhadap apa yang dilakukan oleh masyarakat setempat di masjid tersebut.

Sikap keberagamaan mereka yang terlalu strik dalam berpegang pada hal-hal pokok dalam Islam memosisikan mereka sebagai kelompok fundamentalis Islam. Kelompok ini sangat intensif melakukan kegiatan dakwah bermanhaj salaf al-shalih, dengan pemahaman al-Qur'an dan al-Sunnah secara tekstual. Mereka menolak segala bentuk ibadah baru yang tidak diajarkan oleh Rasulullah SAW (Wahid, 2014 dan Schwartz, 2003). Mereka juga sangat konsisten dalam mengekspresikan dan mengamalkan Sunnah Rasulullah dalam kehidupan sehari-hari. Hal ini terlihat dari ciri mereka yang memanjangkan jenggot, bercelana di atas mata kaki (isbal), dan bercadar 
bagi perempuan (akhwat) (Observasi, Mei 2019); lihat juga Poll, 2014: 4, dan Hasan, 2007: 83-94).

Ciri-ciri keislaman seperti di atas mengarah pada ekspresi keislaman yang simbolik dan formalistik. Sementara itu, masyarakat/jama'ah setempat adalah mereka yang tidak terlalu mengendepankan sisi formal dari ajaran Islam. Perbedaan seperti ini kemudian tampaknya menjadi salah satu faktor terjadinya pertentangan dalam dakwah yang dilakukan kelompok salafi. Pada giliran yang lain, ekspresi keislaman yang berbeda berujung pula pada perebutan fungsi masjid.

Akibat pengajian yang digelar oleh kelompok salafi dan bertentangan dengan pengajian yang dilakukan jama'ah setempat, perebutan fungsi masjid pun terjadi. Sampai saat ini pun hubungan antara salafi dan jama'ah setempat masih bersifat hitamputih. Satu jama'ah dan jama'ah lain di masjid ini tampak saling tidak berteguran (Observasi, Mei 2019), padahal masjid sebagai tempat shalat dan ruang publik (Asya'ri, 2013) diharapkan mampu menyatukan kaum Muslimin.

Masjid Nurul Jam'iyyah sering sekali dikunjungi dan dijadikan oleh para jama'ah luar sebagai tempat pengajian. Di antara alasannya adalah karena masjid ini jauh dari keramaian dan masyarakat yang ada di sekitar masjid lebih terbuka terhadap setiap jama'ah yang datang. Di sisi lain juga karena masjid ini terletak di perkampungan baru (Dusun Baru), di samping Desa Talang Pantai Lama (Dusun Lamo). Seperti yang terdapat pada gambar di bawah ini.

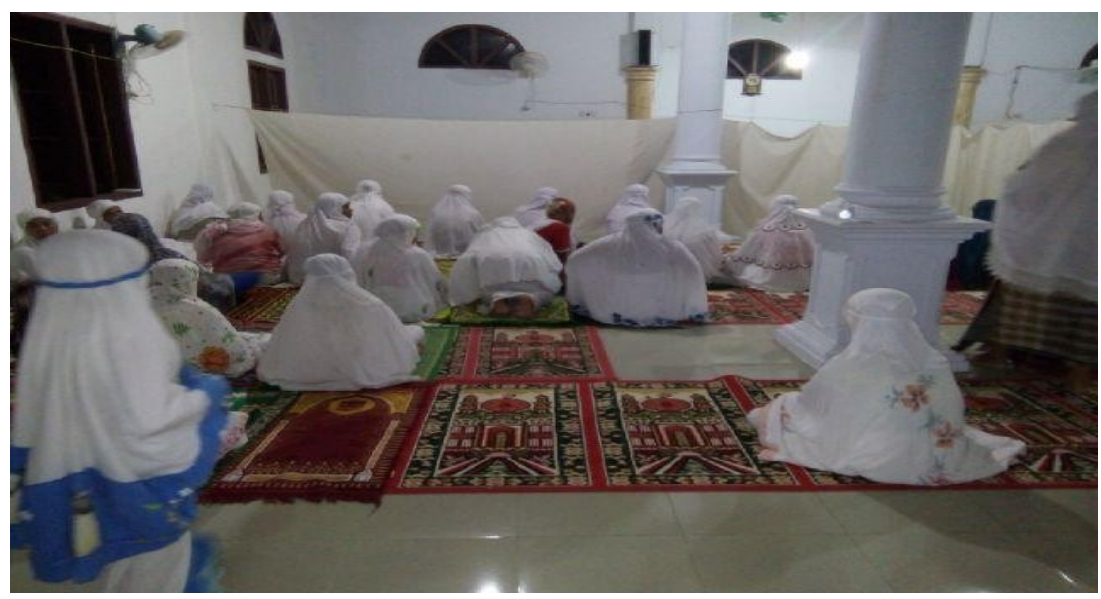

Sumber: Hasil Penelitian

Gambar 2. Jama'ah Ibu-ibu sedang Mendengarkan Pengajian

Berdasarkan informasi yang penulis dapat, kelompok salafi sengaja memanfaatkan masjid tersebut karena masyarakat setempat dianggap masih awam dengan perkara sunnah dan bid'ah. Kehadiran mereka ingin memberikan pencerahan mengenai perkara sunnah tersebut. Ini dibuktikan dengan pengajian mereka yang bukan hanya untuk kelompok internal mereka saja, tetapi juga melibatkan seluruh jama'ah/masyarakat yang shalat berjamaah di masjid tersebut (Wawancara dengan Ustadz Rapiq, 2016). 
Anehnya, mereka yang tergabung dalam kelompok salafi ini tidaklah didominiasi oleh jama'ah luar yang sengaja datang dan hadir pada saat pengajian mereka di masjid ini. Akan tetapi, sebagian besar dari mereka adalah masyarakat setempat yang berdomisili di area masjid tersebut. Justru mereka yang berdomisili ini mengajak teman-teman mereka dari luar untuk hadir dan menggelar pengajian di masjid ini. Sebagai bagian dari masyarakat yang berdomisili di area dekat masjid ini, mereka merasa mempunyai otoritas terhadap masjid. Atas dasar ini pula, Guru Amsir dan masyarakat setempat lainnya merasa tidak punya hak untuk menolak atau melarang pengajian yang dilakukan kelompok salafi itu, karena di dalam pengajian itu tergabung warga setempat.

Setiap orang memiliki hak yang sama untuk menfungsikan masjid, baik untuk pengajian maupun untuk ibadah. Persitegangan hanya terjadi akibat persoalan khilafiyah yang dibesar-besarkan. Salah seorang teman penulis bernama Roina, yang kebetulan rumahnya di samping masjid tersebut menyatakan:

“Keadaan antara salafi dan jama'ah setempat semakin rumit ketika kelompok salafi mulai berani mengambil alih fungsi masjid tersebut untuk pengajian kelompok mereka sendiri. Kelompok salafi tidak segan-segan menggelar pengajian mereka, tanpa mempedulikan hak jama'ah lain yang juga ikut shalat di masjid itu (Wawancara, Mei 2019).

Hal yang sama juga disampaikan Mukaromah:

"Monopoli masjid semakin ditunjukkan pula dengan sikap mereka yang sengaja menunggu jama'ah dari kelompok mereka untuk melakukan shalat berjama'ah. Mereka pun mengumandangkan azan sendiri padahal di masjid-masjid lain sudah lama azan dikumandangkan. Hal ini jelas menimbulkan pertanyaan dari masyarakat awam di sekitar masjid tersebut" (Wawancara, Juni 2019).

Upaya mereka menguasai masjid juga tampak dari keinginan mereka menggantikan dan menformat tradisi/kultur di masjid ini (Wawancara dengan Jama'ah, Mei 2019; Asy'ari, 2013; Hasan, 2007: 83-94). Mereka melarang memukul beduk sebelum azan dikumandangkan. Bagi mereka, tradisi pemukulan beduk harus dihilangkan. Penulis sendiri pernah ditegur waktu itu, ketika penulis memukul beduk sebelum azan. Salah seorang mereka dengan yakinnya berkomentar bahwa "beduk itu bid'ah dan harus ditinggalkan. Azan itu adalah pengganti beduk," dan sebagai kelanjutannya, mereka sering sekali mengambil alih tugas azan, tanpa membunyikan beduk terlebih dahulu. 
Hal demikian tidak sulit dipahami. Kejadian seperti ini memang terjadi dalam konteks masjid yang tidak hanya berfungsi sebagai sarana ibadah. Adanya pemahaman keagamaan yang berbeda di sebuah masjid adalah bukti bahwa masjid tidak hanya untuk ibadah, tapi juga sebagai wahana keragaman sosial keagamaan umat Islam. Akan tetapi, persoalannya perbedaan pemahamaan keagamaan tentu sangat dekat dengan subjektifitas masing-masing orang atau jama'ah. Akibatnya ketika perbedaan pemahamaan keagamaan dikedepankan, maka terjadilah gap atau jarak antara satu orang dengan orang lain.

Pengajian rutin setiap akhir pekan merupakan salah satu kegiatan dakwah yang dilakukan salafi di Masjid Nurul Jami'yyah. Pengajian yang mereka selenggarakan ini boleh dikatakan tandingan terhadap pengajian yang telah lama eksis di masjid tersebut. Meski berada di dalam masjid yang sama, mereka lebih memilih membuat pengajian sendiri. Dari sinilah fanatisme kelompok salafi tampak semakin menguat. Fanatisme yang tinggi terlihat ketika mereka menganggap pengajian yang mereka adakan sebagai pengajian yang al-haq, sementara pengajian masyarakat setempat sebagai pengajian yang sesat (al-dhalal).

Salah satu pengajian yang mereka soroti adalah pengajian yang diasuh oleh Guru Amsir. Menurut mereka, "pengajian Guru Amsir merupakan pengajian ahli bid'ah, yang tidak pantas diikuti." Menyikapi hal ini, Guru Amsir mengungkapkan:

"Kami suka dengan kehadiran jama'ah dari luar di masjid ini, karena dengan kehadiran mereka masjid menjadi selalu aktif, dan tidak ada yang salah jika mereka beribadah di sini. Masyarakat pun semuanya senang. Namun, masyarakat mulai resah dengan adanya indikasi kelompok pengajian yang hadir di sini melakukan propaganda persoalan khilafiyah, bahkan sampai-sampai membid'ahkan amaliyah yang sudah lama dilakukan oleh masyarakat" (Wawancara, Mei 2019).

Selain itu, Pak Ahmad, seorang tokoh agama di masjid ini, yang seringkali terlibat diskusi dengan para kelompok salafi menyampaikan:

"Kami mengakui kehebatan mereka (kelompok salafi) dalam bidang Hadits. Mereka mampu menunjukkan Hadits-Hadits dalam setiap argumentasinya. Bahkan kami sering juga kewalahan menghadapi mereka, tetapi kami selalu mengingatkan kepada mereka agar berhati-hati dalam mengungkap masalahmasalah khilafiyah di hadapan masyarakat awam” (Wawancara, Juni 2019).

Masalah-masalah yang mereka bahas dalam pengajiannya mencakup permasalahan aqidah dan ibadah. Ustad-ustadz yang memberikan pengajian adalah mereka yang telah dididik pada lembaga pendidikan salafi, seperti Ustadz Abu Muhammad, alumni salah satu Pesantren salafi di Jawa Tengah,Ustadz Hafiz dari Sumatera Barat, dan Ustadz Abu Haibah, alumni pesantren salafi yang ada di Jambi. 
Mereka mengkaji kitab-kitab seperti karya-karya Muhammad bin Abdul Wahhab, Ibnu Taymiyah, Nashiruddin al-Albani, dan sebagainya (Wawancara dengan Ustadz Ubaidillah, Mei 2019).

Dalam pengajiannya, terutama ketika mengkaji tentang aqidah, mereka selalu memulai kajian dengan Hadist tentang larangan bid'ah yang sangat terkenal, yaitu “...kullu bid'atin dhalaah wakulla dhalaatin fi al-nar (tiap-tiap bid'ah itu sesat, dan setiap kesesatan itu di dalam neraka). Kemudian dari Hadits ini mereka lanjutkan dengan kritik sosial terhadap realitas keagamaan yang terjadi dalam kehidupan sehari-hari masyarakat. Tahlilan untuk orang mati, Yasinan malam Jum'at, bahkan Yasinan RT, peringatan Mawlid Nabi, semuanya menjadi sasaran empuk yang mereka kritisi. Ustadz Abu Muhammad al-Salafy berkata:

"Begitu banyak perkara bid'ah di sekitar lingkungan kita. Tahlilan, Yasinan, kirim al-Fatihah, begitu pula Barzanji, semua itu adalah bid'ah dan tidak pernah diajarkan oleh Rasulullah SAW. Andaikan perkara itu baik, maka pasti generasi salaf al-salih sebelum kita telah melakukan itu. Sungguh masyarakat kita telah banyak yang hanyut dalam taklid buta" (Wawancara, Mei 2019).

Dalam kajian Hadits, ketika membahas bab tentang zikir, Ustadz Abu Haibah juga menegaskan:

'Zikir yang diamalkan itu haruslah zikir yang ada di dalam al-Qur'an dan al-Sunnah, serta pernah diamalkan oleh Rasulullah dan para generasi salaf. Terkadang masyarakat kita terlalu banyak mengarang zikir tanpa ada dasarnya dari al-Qur'an dan al-Sunnah, akibatnya bukan pahala yang didapat, tapi malah dosa. Berzikirpun tidak disunnahkan berjama'ah. Zikir jama'ah itu bid'ah hukumnya" (Wawancara, Mei 2019).

Jika dilihat dari materi pengajian mereka, dapat dikatakan bahwa doktrin keagamaan yang mereka ajarkan tidak jauh berbeda dengan doktrin salafi secara umum di tempat-tempat lain, yaitu menolak tradisi keislaman yang tidak sejalan dengan teks al-Quran dan Hadits. Hal ini tentu pada gilirannya semakin memperkuat gelombang fanatisme sunnah di tengah masyarakat. Pada sisi lain, fanatisme kelompok salafi berakibat pada menguatnya sikap asosial dalam pergaulan kehidupan sehari-hari. Hal ini dibuktikan dengan mereka yang seringkali absen dalam acara-acara sosial kemasyarakatan. Mereka menganggap acara-acara masyarakat penuh dengan hal-hal bid'ah, seperti kegiatan do'a bersama setelah atau di penghujung suatu acara. Penulis juga pernah mendapat aduan dari keluarga penulis yang kebetulan aktif berjama'ah di masjid tersebut. Ia mengatakan: 


\begin{abstract}
"Setelah shalat kami berzikir bersama secara berjama'ah dengan dipimpin oleh pak Imam, sementara para jama'ah salafi yang tidak suka dengan amaliyah tersebut, malah ribut ngobrol sesama mereka dengan suara yang keras. Mereka tampak sekali menganggap remeh amaliyah yang dilakukan oleh jama'ah setempat" (Wawancara dengan Mala, Juni 2019).
\end{abstract}

Sikap kaku dan strik dalam beragama pada batas tertentu cukup sulit bersentuhan dengan kehidupan sosial masyarakat. Hal ini karena memang Islam sebagai agama tidak mudah ditafsirkan apalagi didakwahkan dalam konteks masyarakat yang berbudaya, terlebih Islam yang sudah membaur dengan kebudayaan masyarakat seperti di Indonesia. Namun Islam, selain sebagai sesuatu yang absolut dalam tataran normatif, ia tidak dapat mengelak dari sentuhan sosial masyarakat yang kemudian menampilkan wajah Islam yang berbeda antara satu dengan yang lain. Hal inilah yang terjadi dalam dinamika tarik menarik antara dakwah salafi dan masyarakat setempat. Pada giliran yang lain, dakwah salafi dalam konteks Masjid Nurul Jam'iyyah di atas terlihat tidak hanya dijauhi masyarakat setempat tapi juga menjadi penghambat bagi keberhasilan dakwah salafi sendiri dalam menembus sosial masyarakat. Hal ini relevan dengan kesimpulan Wahib (2017).

Ketidak-bijaksanaan dalam menjalankan komunikasi-dakwah ini tidak jarang telah menjadikan istilah fundamentalisme berkonotasi negatif, seperti dijelaskan pada bab terdahulu. Dalam konteks inilah komunikasi dakwah seorang fundamentalis salafi dapat didiskusikan (Bakti, 2000).

Beragama secara fundamentalistik memang menjadi kebanggaan setiap individu yang tergabung dalam kelompok salafi yang nimbrung di masjid Nurul Jamiyyah. Tidak jarang, di antara mereka sengaja memamerkan apa yang telah mereka pelajari dari Ustadz-ustadz mereka dengan menyebut mereka merujuk langsung kepada alQur'an dan al-Sunnah, sementara jama'ah setempat dalam pandangan mereka, hanya berpegang pada pendapat si A dan si B (Observasi, Mei 2019). Karenanya, kelompok ini tanpa ragu mengukuhkan diri mereka sebagai pengikut sunnah sejati.

Dalam batas tertentu, sikap fundamentalis kelompok salafi di atas menemukan relevansinya secara akademik. Hal ini sejalan dengan Muhammad Imarah (1968) yang melihat bahwa bersikap fundamentalis dalam Islam adalah sebuah kewajaran karena ia berhubungan dengan komitmen keberagamaan seseorang. Maka adalah sesuatu yang wajar ketika seseorang yang beragama berpegang teguh dengan dasar-dasar agamanya. Hal ini diperkuat oleh Khaled Abou e-Fadl (2005) yang memandang bahwa berpegang pada hal-hal yang bersifat ushul (pokok) dalam Islam menjadi trend semua kalangan muslimin bahkan oleh mereka yang menyatakan dirinya sebagai muslim progressif sekalipun. Salafi di Masjid Nurul Jam'iyyah pun menunjukkan sikap yang demikian dalam beragama dan berdakwah. 
Namun prinsip fundamentalis seperti di atas menjadi problematik ketika disertai dengan sikap dakwah yang strik dan sering menyalahkan kelompok lain. Apa yang diungkapkan oleh Wahib (2017) sebagai Arabisasi yang dilakukan kelompok salafi menemukan relevansinya di sini. Juga Ayang Utriza Yakin (2018) yang melihat bahwa kelompok salafi berdakwah secara frontal bahkan mereka tidak siap berdemokrasi dan menghargai hak-hak orang lain untuk berbeda pendapat.

Pernyataan salah seorang jama'ah di Masjid Nurul Jam'iyyah menunjukkan hal ini. "Alih-alih menghargai perbedaan, mereka malah menyalahkan dan mengatakan sesat," ungkap salah seorang jama'ah yang kebetulan juga alumni salah satu perguruan tinggi dan bertempat tinggal di sekitar masjid ini (Wawancara dengan Roziq, Mei 2019). Warga yang lain di sekitar masjid ini juga menyatakan, "kami tidak suka dengan cara mereka menyampaikan kajiannya. Meskipun mereka merujuk kepada al-Qur'an dan al-Sunnah. Kami berharap mereka segera menghentikan pengajian mereka atau kalau tidak, mereka harus meninggalkan masjid tersebut" (Wawancara, Juni 2019). Bahkan menyangkut hal ini, penulis sendiri juga pernah mewawancarai dan terlibat diskusi dengan kelompok salafi. Ketika penulis menanyakan beberapa hal tentang soal khilafiyah, mereka menjawab:

"Khilafiyah memang ada. Kami tidak pernah menafikan adanya khilafiyah. Imam yang empat saja mereka berkhilafiyah, tetapi kita harus berpegang teguh kepada al-Qur'an dan al-Sunnah yang sahih Jika ada hadist yang sahih, pendapat ulama harus kita tinggalkan. Dalam soal bid'ah hasanah, meskipun ada di antara Ulama yang membagi bid'ah menjadi bid'ah hasanah, tetapi tetaplah bid'ah hasanah itu tidak ada. Kita harus pegang hadist ini dan meninggalkan perkataan Ulama" (Ceramah Ustadz Abu Muhammad, Mei 2019).

Sikap strik seperti di atas membuat jama'ah setempat merasakan kehadiran kelompok ini sebagai sesuatu yang asing dan dalam batas tertentu sangat keras dan ekstrem, karena kelompok ini tidak henti-hentinya merongrong masyarakat untuk meninggalkan amaliyah keagamaan mereka dengan beralih mengikuti al-Qur'an dan alSunnah.

Sikap seperti ini merupakan sikap menutup diri dari komunikasi yang terbuka. Lisnyansky (2018) menyimpulkan bahwa salafi hanya akan berinteraksi dengan kelompok lain (muslim atau non-mulism) jika itu berhubungan dengan prinsip keagamaan yang mereka anut. Tampaknya bagi salafi, tidak ada ruang untuk mengekspresikan perbedaan dalam keberagamaan. Bagi mereka, persatuan itu adalah persatuan dalam al-Qur'an dan al-Sunnah. Orang-orang yang melenceng dari al-Qur'an dan al-Sunnah harus ditolak dan dijauhi, kendatipun Ulama besar seperti Imam Syafi'i. Mereka tidak melihat pentingnya mengedepankan komunikasi yang baik dalam dinamika perbedaan pemahaman. Karenanya, upaya kelompok salafi menolak 
pandangan atau pemahaman lain serta mengajak kembali kepada al-Qur'an dan alSunnah terlihat paradoksial, karena pada saat yang sama mereka justru mengajak orang lain untuk mengikuti manhaj mereka sendiri, yaitu apa yang mereka pahami dari alQur'an dan al-Sunnah.

Terlepas dari itu, lagi-lagi kembali kepada al-Qur'an dan al-Sunnah bukanlah persoalan, bahkan sebuah kesepakatan, namun yang menjadi persoalan adalah cara komunikasi dan dakwah. Komunikasi-dakwah yang dibangun oleh kelompok salafi adalah komunikasi top-down (atas-bawah) dan satu arah dengan pendekatan struktural dan karenanya sangatlah strik dan kaku. Kelompok ini terlihat tidak bersedia membuka diri untuk berkomunikasi secara kultural.

Model komunikasi top-down ini dikonstruksi dalam tradisi komunikasi sekuler. Komunikasi sekuler, yang didominasi oleh epistemologi Barat, hampir selalu menempatkan komunikan pada posisi yang harus menerima informasi secara utuh. Hal ini merujuk perspektif yang didukung oleh mazhab komunikasi dengan pola $S M C R, E$, dan convergence. Sistem ini ditekankan oleh C. Shanon dan W. Weaver (1949) dalam bentuk komunikasi satu arah, yaitu S (sender)-M (massage)-C(channel)-R (receiver), namun komunikasi satu arah ini, menurut H. Laswell (1960), sangat membutuhkan "effects" apabila si penerima menyadari dan merasakan pentingnya suatu pesan yang datang. Pada konteks ini, pengirim pesan masih menjadi pusat dan penentu bagi kesuksesan sebuah komunikasi.

Sementara itu, di dalam Islam, suatu komunikasi didasarkan pada prinsip keseteraan dan egalitarianisme. Pesan komunikasi yang disampaikan dalam Islam tidak semata-mata harus dipaksakan kepada orang lain (Hamid Mowlana, 2007: 23-33). Hal ini mendukung konsep uses and gratification (manfaat dan kepuasan). Dalam konsep ini, menurut Branston dan Stafford (2010), seseorang mengidentifikasi dirinya sebagai pembaca yang aktif, penonton yang bebas mengontrol remote televisi, daripada sekadar menjadi pembaca pasif yang hanya menjadi korban penipuan dan pencucian otak oleh media. Dominasi pengirim atas penerima telah hilang dalam pendekatan ini. Penerima pesan hanya akan menerima atau mengakses pesan sesuai dengan kebutuhan dan kepuasan yang ia peroleh.

Jika dilihat dari kacamata dakwah Islam, konsep manfaat dan kepuasan sejalan dengan prinsip tabligh, yang berarti menyampaikan sesuatu tanpa adanya paksaan kepada si penerima pesan untuk menerimanya, dan penerima hanya akan menerima pesan jika pesan itu bermanfaat dan berhubungan dengan kebutuhannya. Ini bisa dirujuk dalam beberapa ayat al-Qur' an misalnya Surat al-A'la ayat 9-10:

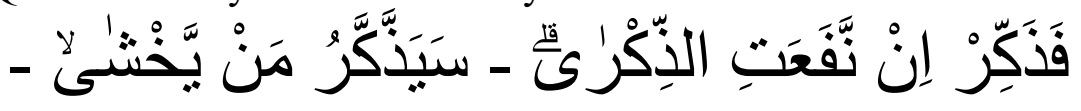

Oleh sebab itu berikanlah peringatan karena peringatan itu bermanfaat, Orang yang takut (kepada Allah) akan mendapat pelajaran. 
Surat al-Ghasyiyah ayat 21-26:

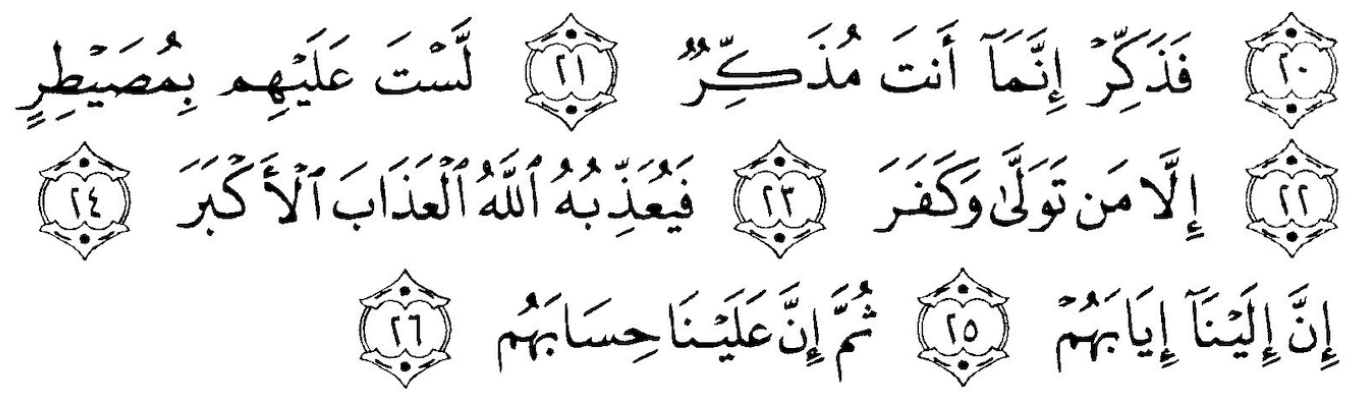

Maka berilah peringatan, karena Sesungguhnya kamu hanyalah orang yang memberi peringatan. Kamu bukanlah orang yang berkuasa atas mereka, tetapi orang yang berpaling dan kafir, Maka Allah akan mengazabnya dengan azab yang besar. Sesungguhnya kepada Kamilah kembali mereka. Kemudian sesungguhnya kewajiban Kami-lah menghisab mereka.

Surat Yasin ayat 10-11:

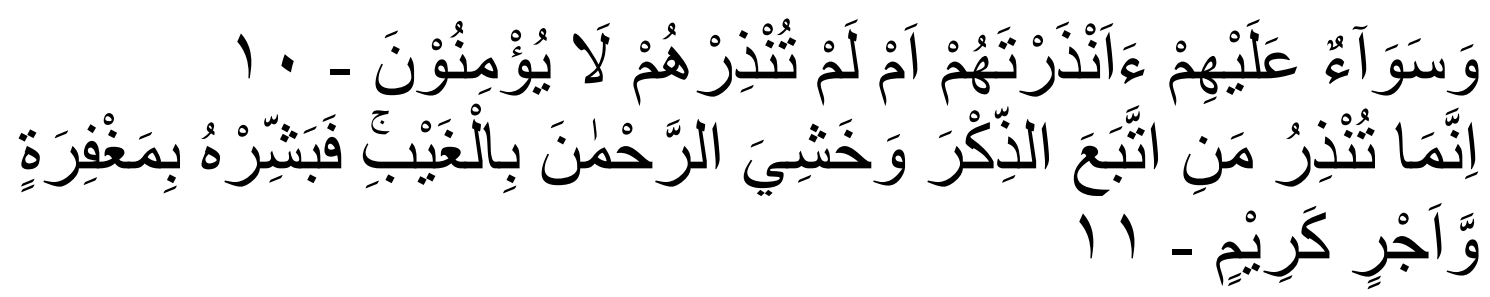

"Dan sama saja bagi mereka Apakah kamu memberi peringatan kepada mereka ataukah kamu tidak memberi peringatan kepada mereka, mereka tidak akan beriman juga. Sesungguhnya kamu hanya memberi peringatan kepada orang-orang yang mau mengikuti peringatan dan yang takut kepada Tuhan yang Maha Pengasih, walaupun mereka tidak melihat-Nya. Maka berilah mereka kabar gembira dengan ampunan dan pahala yang mulia."

Surat Yasin ayat 17:

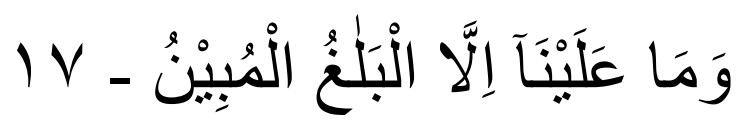

"Dan kewajiban kami hanyalah menyampaikan (perintah Allah) dengan jelas." 
Pada ayat-ayat tersebut dijelaskan bahwa pengirim pesan tidak punya kekuasaan untuk membentuk diri penerima pesan. Penerimalah yang menentukan untuk menerima atau menolak sebuah pesan. Selain itu, model komunikasi top-down juga tidak sejalan dengan prinsip metode dakwah dalam Islam. Tiga metode dakwah utama, al-Hikmah, al-Maw'idzah Hasanah, dan al-Muja<dalahbil Ahsan, merupakan wujud moderasi dakwah dalam Islam. Terlebih metode al-mujadalah (debat atau diskusi), yang pelaksanaannya harus dilakukan dengan cara terbaik (Ahsan) (Zaedan, 1975). Ini menunjukkan bahwa di dalam Islam tidak terdapat model dakwah top-down. Ayat alQur'an yang terkenal mengenai kalimatin sawa yang terdapat dalam Surat Ali Imran ayat 64 juga menekankan aspek diskusi dan kesetaraan serta tidak sama sekali berbentuk komunikasi top-down.

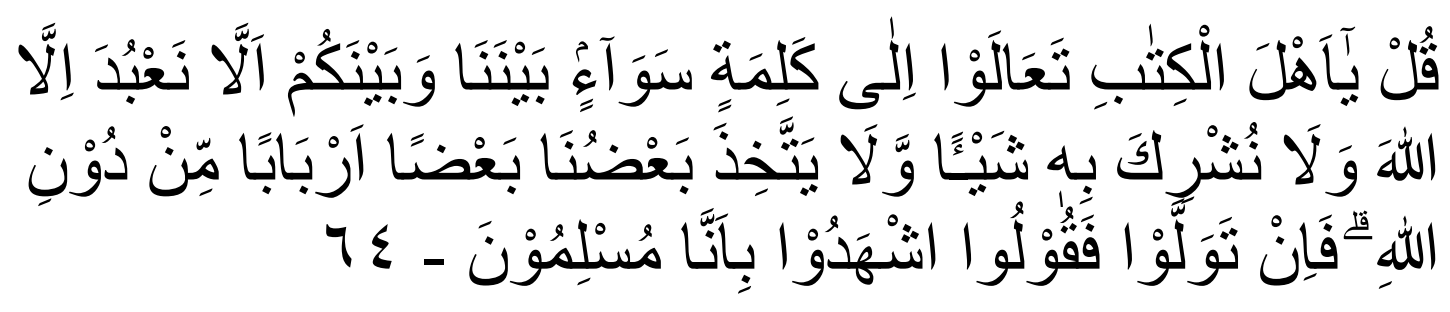

Katakanlah (Muhammad): "Wahai ahli kitab, marilah (berpegang) kepada suatu kalimat (ketetapan) yang tidak ada perselisihan antara kami dan kamu, bahwa tidak kita sembah kecuali Allah dan tidak kita persekutukan dia dengan sesuatu pun dan tidak (pula) sebagian kita menjadikan sebagian yang lain sebagai Tuhan selain Allah". Jika mereka berpaling Maka Katakanlah kepada mereka: "Saksikanlah, bahwa kami adalah orang-orang yang berserah diri (kepada Allah)."

Dalam ayat ini Allah memerintahkan untuk menyeru para Ahli Kitab dengan kata "Ta'alaw" yang berarti "marilah." Begitu pula penggunaan redaksi kalimatin sawain baynana wa bayna kum (suatu kalimat/ketetapan yang tidak ada perselisihan antara kami dan kamu). Penggunaan kata "marilah" merupakan bentuk ajakan persuasive yang tidak memaksa sama sekali. Begitu pula kalimat "antara kami dan kamu" yang menunjukkan bahasa kompromi, kebersamaan, dan keseteraan. Ini merupakan bahasa komunikasi dalam al-Qur'an. Artinya al-Qur'an sendiri dalam mendakwahkan persoalan fundamental aqidah saja sangat santun dan tidak pernah melakukan pemaksaan, apalagi dalam persoalan khilafiyah. Karena itu, tidak benar sekali ketika dakwah dilakukan dengan model komunikasi top-down.

Komunikasi Islam adalah komunikasi yang sangat menghargai eksistensi orang lain. Jika saja kelompok salafi melihat inti perbedaan yang ditampilkan oleh orang lain sebagai manifestasi kultural-intelektural atas pemahaman masing-masing orang terhadap al-Qur'an dan al-Sunnah, mungkin tidak akan terjadi persitegangan yang rumit dan problematik antara salafi dan masyarakat setempat, seperti yang terjadi di Masjid 
Nurul Jam'iyyah di atas. Dalam kaitan ini, dapat dikatakan bahwa komunikasi Islam tidak berfungsi meruntuhkan apa yang menjadi pandangan dan keyakinan orang lain, tetapi berupaya memahami dan menghargainya (Bakti, 2011). Dalam hal pembagian bid'ah misalnya, orang yang membagi bid'ah menjadi dua, bid'ah hasanah dan bid'ah sayyi'ah, berpegang kepada al-Qur'an dan al-Sunnah. Begitu pula mereka yang menolak adanya pembagian bid'ah menjadi dua, juga berpegang kepada al-Qur'an dan al-Sunnah. Karena itu, sejatinya tidak ada yang salah mengenai perbedaan pemahaman selama kaidah pemahaman al-Qur'an dan Hadist masih dalam batas-batas yang dibenarkan oleh Ulama-ulama Islam dan tidak bertentangan dengan manhaj Rasulullah SAW, tetapi lagi-lagi yang menjadi persoalan adalah manhaj Rasulullah itu seperti apa? Inipun sangatlah interpretatif.

Selain itu apa yang dikatakan oleh Ustadz salafi bahwa masyarakat setempat di Talang Pantai sudah melupakan al-Qur'an dan bahkan sangat jauh dari al-Qur'an, tidak dapat semata-mata dibenarkan, karena yang penulis lihat justru masyarakat di Desa ini tidak anti dengan al-Qur'an dan al-Sunnah. Buktinya anak-anak ramai mengaji alQur'an setiap usai shalat Magrib sampai shalat Isya. Ini jelas menunjukkan adanya kesadaran orang tua akan pentingnya al-Qur'an. Di samping itu, mereka juga mengkaji kitab-kitab tafsir dan Hadis seperti yang dilakukan oleh Guru Amsir. Meskipun diakui memang masyarakat setempat belum sampai pada tingkat pemahaman mendalam terhadap kandungan al-Qur'an, tetapi secara prinsip mereka tidak pernah tidak menjadikan al-Qur'an sebagai pegangan hidup. Bahkan salah seorang warga ketika ditanya, mengapa ia memerintahkan anak-anaknya belajar mengaji setiap habis Magrib di masjid itu? Ia menjawab:

"Iya, karena kita sebagai Muslim harus bisa membaca dan mengerti alQur'an. Anak-anak zaman sekarang banyak yang tidak bisa membaca al-Qur'an. Apalagi kehidupan sekarang banyak godaannya, anak-anak bebas dalam pergaulan. Maka apalagi pegangan hidup kalau bukan alQur'an" (Wawancara, Juni 2019).

Begitupula, upaya mentradisikan kegiatan Yasinan RT dalam kehidupan masyarakat Talang Pantai ini juga ditujukan sebagai upaya menjinakkan masyarakat agar bisa lebih dekat dengan bacaan al-Qur'an. Jadi tradisi Yasinan RT tidak bisa dilihat sebagai bentuk diskriminasi terhadap ayat-ayat atau surat-surat yang lain. Hal itu lagi-lagi, tegas Guru Amsir, dilakukan agar masyarakat yang jarang membaca alQur'an bisa membaca al-Qur'an. Itulah tujuan Yasinan RT, karena jika masyarakat langsung diajak membaca al-Qur'an 30 Juz dalam satu malam, pasti akan memberatkan mereka (Wawancara dengan Guru Amsir, Mei 2019).

Bukti lain terlihat dalam ceramah-ceramah yang disampaikan oleh Guru Amsir, di mana ia selalu menggunakan ayat al-Qur'an dan Hadis. Apalagi Guru Amsir sendiri, 
beliau adalah seorang yang hafal al-Qur'an. Kajian kitab Tafsir Ibnu Katsir yang ia gunakan dalam mengajar juga merupakan tafsir yang kuat dengan tradisi Hadits. Demikian pula kitab Sayral-Sa $a$ ikin karya Abdal-Shamad al-Palimbani yang diajarkannya, merupakan saduran dari Ihya'Ulumal-Din, sebuah kitab tasawwuf yang berupaya mendamaikan antara mistisisme dan syari'ah, karya Hujjat al-Islam Imam alGhazali (Fahturrahman, 2016).

Fakta-fakta di atas menunjukkan bahwa masyarakat setempat, termasuk pengajian Guru Amsir yang dipandang bid'ah itu masih memiliki komitmen terhadap al-Qur'an dan al-Sunnah. Di sisi lain jutru yang tampak problematik adalah cara komunikasi-dakwah kelompok salafi. Sikap dakwah salafi yang tiba-tiba secara frontal menyalahkan amaliyah masyarakat setempat yang sudah mapan membuat masyarakat setempat merasa terusik, sementara masjid (tempat ibadah itu) adalah public space bagi kaum muslimin (Hoexter, 2000), di mana semua orang bebas memanfaatkannya tanpa intimidasi dan gangguan.

\section{Simpulan}

Dari paparan di atas dapat disimpulkan bahwa kegiatan dakwah salafi di Masjid Nurul Jam'iyyah dilakukan dengan cara strik dan rigid. Pemaksaan pendapat dan penegasian kelompok lain yang berbeda adalah ciri yang melekat pada dakwah mereka. Hal ini di satu sisi tidaklah bermasalah, karena bersikap fundamentalis dalam menjalankan Islam bukanlah sesuatu yang membahayakan. Namun di sisi lain, fundamentalisme Islam bisa menjadi problemtik ketika dipaksakan untuk diterima oleh orang lain dalam proses dakwah yang dilakukan. Pada titik ini, Islam terkadang tampak tidak ramah dengan realitas masyarakat yang berkembang dengan segala dinamikanya.

Karenanya, ekstremitas dakwah tidak terletak pada substansi dakwah yang ditampilkan salafi, tetapi pada komunikasi-dakwah yang digunakan. Komunikasidakwah bukan hanya berkutat pada inti ajaran Islam yang didakwahkan, tetapi pada bagaimana kemudian pesan-pesan itu disampaikan atau ditransmisikan kepada orang lain. Maka ada sebuah ungkapan yang menarik dikemukakan 'al-Thariqah Ahamm min al-Maddah' (cara atau metode lebih penting dari pada materi).

Penulis menemukan bahwa dakwah yang dilakukan kelompok salafi di Masjid Nurul Jam'iyyah di atas cenderung mengabaikan aspek komunikasi dakwah ini. Komunikasi dakwah yang dapat diterapkan adalah komunikasi dakwah yang berdiri di atas egalitarianisme dakwah, anti pemaksaan terhadap orang lain. Hal ini jelas merupakan inti dari ajaran Islam yang rahmatan lil alamin.

Apa yang tampak dari dakwah salafi dalam paparan artikel ini, penulis sadari memang tidak bisa digeneralisasikan untuk seluruh dakwah salafi, tetapi kasus Masjid Nurul Jam'iyyah di atas merupakan salah satu kasus yang berkembang di masyarakat. Penulis melihat bahwa tarik menarik antara masyarakat dan kelompok salafi terjadi 
setelah kelompok tersebut berupaya mengambil alih fungsi masjid untuk kepentingan sendiri dan berusaha mengubah kultur yang sudah lama berjalan di masjid ini.

Sebagai rekomendasi, seorang fundamentalis sejati dapat melakukan langkahlangkah kultural dalam upaya mengubah masyarakat secara perlahan-perlahan, dan tidak harus dengan frontal. Penulis menyarankan penting bagi pelaku dakwah untuk mempertimbangkan konteks dan realitas yang berkembang dalam kehidupan mad'u ketika mendakwahkan Islam, apalagi ketika menyinggung persoalan khilafiyah, dakwah harus mengedepankan komunikasi, bukan emosi.

\section{Referensi}

Asy'ari, Su'aidi. (2013). Managing Islamic public space responses of Sumantran Malay muslims toward neo-anti bid'ah movement. Journal of Indonesian Islam, 7 (2), 1 20.

Armbrost, Andereas. (2019). A profile of religion fundamentalism and terrorist activism. Defence Against Terrorism Review, 2 (1).

Al-Maraghi, Ahmad Mustafa. (1998). Tafsir al-maraghi. Mesr: Dar al-Fikr.

Appleby, R. Scott. (2000). The ambivalence of the secred religion: religion, violance and reconciliation. New York: Cernegia Corporation.

Bangstad, Sindre \& Ling, Marius. (2015). Da'wa is Our Identity'-Salafism and IslamNet's Rationales for Action in a Norwegian Context. Journal of Muslims in Europe, 1-23. Doi 10.1163/22117954-12341307. Diakses dari https://www.researchgate.net/publication/282148353 'Da'wa is_Our_dentity'Salafism_and_IslamNet's_Rationales_For_Action_in_a_Norwegian_Context' [accessed Mar 05 2020].

Barkun, Michael. (2004). Religious violance and the myth of fundamentalism. Dalam Religious fundamentalism and political extremism, Leonard Weinberg dan Amin Pedazur, eds. London; Frank Cass Publisher.

Bar, Shmuel. (2008). The religious sources of Islamic terrorism. Dalam The theory and practice of Islamic terrorism an anthropology, Marvin Perry dan Howard E. Negrin (eds.). New York: Palgrave Macmillan.

Bakti, Andi Faisal. (2000). Major conflicts in Indonesia: How can communication contribute to a solution. Review of Human Factor Studies, 6 (2), 21-40.

Bakti, Andi Faisal. (2011). Unity in diversity among muslims in the Malay world: literary works as seen from the perspective of communication. Rainbows of Malay Literature and Beyond, 45-80.

Boubekeur, Amel. (2008). Salafism and Radical Politics in Postconflict Algeria, Carnegie Endowment for International Peace. 1779 Massachusetts Avenue, NW.

Branston, Gill \& Stafford, Roy. (2010). The media student's book. New York and London: Routledge. 
Chaplin, Chris. (2018). Salafi activism and the promotion of a modern Muslim identity: evolving mediums of Da'wa amongst Yogyakartan university students. South East Asia Research, 26 (1). pp. 3-20. ISSN 0967-828X DOI: 10.1177/0967828X17752414.

Commins, David. (2009). The wahhabi mission and Saudi Arabia. London: I.B.Tauris.

Chanon, C., \& Weaver, W. (1949). The mathematical theory of communication. III Carbondale: University of Ilinois Press.

Diraniyah, Mujahid Ma'mun. 2008. Fusul fi al-da'wah wa al-islah. Saudi Arabia: Dar al-Manarah.

El-Fadl, Khaled Abou. (2005). Selamatkan Islam dari muslim puritan. Jakarta: Serambi.

Esposito, John L. (2002). Unholy War: Terror in the name of Islam. New York: Oxford University Press.

Esposito, John L. (2010). The future of Islam. New York: Oxford University Press.

Edwards, Beverly Milton. (2005). Islamic fundamentalism since 1945. New York: Routledge.

Fathurrahman, Oman. (2016). Neo-Sufisme, Ghazalian Abdussamad al-Palimbani. Diakses melalui oman.uinjkt.ac.id.

Hafiz Mustafa Abu Najah. (2012). Mengusut Bid'ah Hasanah. Majalah al-Furqon, edisi 171. Vol.12, tahun ke-15, 45.

Hasan, Noorhaidi. (2007). The salafi movement in Indonesia: Transnational dynamics and local development. Comparative Studies of South Asia, Africa and the Middle East. 27 (01), (2007), 83-94.

Iqbal, A. M. (2014). Internet, Identity and Islamic Movements: The Case of Salafism In Indonesia. Islamika Indonesiana, 1:1. Diakses dari https://www.researchgate.net/publication/273084029 Internet Identity_and_Isla mic Movements The Case of Salafism in Indonesia.

Ibn Taymiyyah. (2005). Majmu' fatwa. Madinah: Dar al-Wafa'.

'Imarah, Muhammad. (1968). al-Usuliyah bayn al-gharby wa al-Islam. Beirut: Dar alSyuruq.

'Imarah, Muhammad. (2004). Ma'rakat al-musthalahat bayn al-gharby wa al-Islam. Mesr: Nahdhat Misr.

Laswell, H. (1960). The structure and function of communication in society. Dalam W. Shramm (ed), Mass communication. Illinois: University of Illinois.

Lisnyansky, Dina. (2018). From Da'wa in Europe to European Da'wa: The Muslim Brotherhood and the Salafiyya in France and Britain. The Journal for Interdisciplinary Middle Eastern Studies, 1, pp. 79-103.

Lubis, M. Ridwan. (2015). Agama dalam diskursus intelektual dan pergumulan kehidupan beragama di Indonesia. Jakarta: Pusat Kerukunan Umat Beragama Sekretariat Jenderal Kementerian Agama RI. 
Hoexter, M. (2002). The public sphere in muslim societies. New York: State University of New York Press.

Madjid, Nurcholish. (2008). Tradisi Islam. Jakarta: Dian Rakyat dan Paramadina.

Meleagrou-Hitchens, Alexander. (2018). Salafism in America History, Evolution, Radicalization. Program on Extremism, The George Washington University, October.

Marsden, George M (2006). Fundamentalism and American culture. New York: Oxford University Press.

Mowlana, Hamid. (2007). Theoretical perspectives on Islam and communication. China Media Research. 3 (4), 23-33. (Diakases pada 12 Maret dari http://www.chinamediaresearch.net).ress, 2002).

Rajab, Wail Muhammad Said. (2011). Wasathiyyat al-Rasul fi da' watihi ila al-Islam. Jami'ah al-Anbar.

Umar, Nasaruddin. (2014). Deradikalisasi pemahaman Al-Qur`an \& Hadis. Jakarta: PT Elex Media Komputindo.

Powers, P. (2007). Persuasion and coercion: A critical review of philosophical and empirical approaches. HEC Forum, 19: 125. https://doi.org/10.1007/s10730007-9035-4.

Pall, Zoltan. (2014). Kuwaiti salafism and its growing influence in the Levant. Carnegie Endoment for International Paece. Paper.

Sunarwoto. (2016). "Salafi Dakwah Radio: A Contest for Religious Authorit." Archipel, 91, p. 203-230. https://doi.org/10.4000/archipel.314.

Wahib, Ahmad Bunyan. (2017). Being Pious among Indonesian Salafis. Al-Jāmi 'ah: Journal of Islamic Studies, Vol. 55, no. 1 (2017), pp.1-26. Doi: 10.14421/ajis.2017.551.1-26.

Wahid, Din. (2014). Nurturing the salafi manhaj: A study of salafi pesantrens in contemporary Indonesia. Utrecht University.

Wahid, Din. (2017). Challenging Religious Authority the Emergence of Salafi Ustadhs in Indonesia. Journal of Indonesian Islam, Volume 06, Number 02, December, pp. 2-20.

Yakin, A. (2018). Salafi Dakwah and the Dissemination of Islamic Puritanism In Indonesia: A Case Study of the Radio of Rodja. Ulumuna, 22(2), 205-236. https://doi.org/10.20414/ujis.v22i2.335.

Zaedan, Abdul Karim. (1975). Usul al-da'wah. Baghdad: Maktabat Ilmiyyah. 